Fakultas komputer

Muhammad Rizq Daffa Jodi

Section 01

\title{
Algoritma dan Struktur data
}

\author{
Muhammad Rizq Daffa Jodi
}

195120026

Fakultas komputer

daffajody.student@umitra.ac.id

Algoritma

Algoritma adalah urutan aksi-aksi yang dinyatakan dengan jelas dan tidak rancu untuk memecahkan suatu masalah dalam rentang waktu tertentu. Setiap aksi harus dapat dikerjakan dan mempunyai efek tertentu. Algoritma merupakan logika, metode dan tahapan (urutan) sistematis yang digunakan untuk memecahkan suatu permasalahan.

Dalam ilmu matematika dan komputer, pengertian algoritma merupakan prosedur dari beberapa langkah demi langkah untuk penghitungan. Algoritma dipakai untuk penghitungan, penalaran otomatis, dan pemrosesan data. Pengertian algoritma ialah suatu metode yang efektif diekspresikan sebagai rangkaian yang terbatas dari beberapa instruksi yang telah dijelaskan dengan baik guna menghitung sebuah fungsi. Susunan algoritma dimulai dari kondisi awal dan input awal, instruksi tersebut mendeskripsikan komputasi yang apabila itu dieksekusi serta diproses dengan melewati urutan-urutan kondisi terbatas yang terdefinisi dengan baik, sehingga dapat menghasilkan output atau keluaran dan berhenti di kondisi akhir yang telah ditentukan.

Algoritma dapat dituliskan dengan banyak cara, mulai dari menggunakan bahasa alami yang digunakan sehari-hari, simbol grafik bagan alir (flowchart), sampai menggunakan bahasa pemrograman seperti bahasa $\mathrm{C}$ atau $\mathrm{C}++$. Penulisan algoritma tidak terikat pada suatu aturan tertentu, tetapi harus jelas maksudnya dari suatu penulisan algoritma untuk tiap langkah algoritmanya. Notasi algoritma bukan merupakan notasi bahasa pemograman, 
namun notasi ini dapat diterjemahkan kedalam berbagai bahasa pemograman. Algoritma dapat dinotasikan dalam beberapa cara

\section{Langkah - Langkah Membuat Algoritma}

Beberapa langkah yang harus di perhatikan oleh pemogram sebelum mengimplementasikan suatu permasalahan dalam program adalah :

1. Mendefinisikan masalah Tujuan dari mendefinisikan masalah adalah untuk memahami masalah secara mendalam .langkah ini harus dengan apa yang akan di input pada program ,perintah perintah apa yang akan di gunakan dan bagaimana bentuk outputnya .jadi harus di pahami benar-benar permasalahan yang ada .salah asumsi tentang masalah yang ada ,akan berakibat program yang di buat tidak sesuai yang di kehendaki.

2. Mencari solusi untuk masalah Setelah dipahami permasalahan yang ada baik itu masukan atau input ,perintah yang di gunakan atau keluara yagn di inginkan baru di cari jawabanya atau solusinya untuk memecahkan masalah sehingga masalah tersebut dapat terselesaikan dengan baik ,apabila masalah yang di hadapi terlalu besar kita dapat membagi menjadi beberapa modul yang dapat memudahkan untuk menyelesaikan masalah .modul tersebut dinaman fungsi. misalnya ada suatu permasalaha sebagai berikut :buatlah program untuk menghitung luas dan keliling persegi panjang .dalam hal ini ada beberapa ahal yang diketahui yaitu bagaimana saja yang menjadi input,proses yang diloakukan apa saja dan outputnya apa saja.

3. Memiliki teknik pemecahan masalah dan algoritma Dalam pemecaha masalah memerlukan suatu teknik pemecahan masalah yang tepat, dalam hal ini nanti akan di tuangkan dalam suatu algoritma ,algoritma di buat dengan tujuan untuk menyelesaikan suatu masalah algoritma tidak bisa sekali jadi tetapi akan di kaji berulang -ulan sampai di peroleh algoritma yang tepat, benar dan relevan .Algoritma harus memiliki kebenaran secara logika sehingga siap di implementasiakan dalam program .

4. Menulis program, $\mathrm{C}++$ merupakan pada bahasa pemograman tingkat tinggi contoh program dari masalah luas dan keliling persegi panjang adalah

5. Melakukan testing dan debugging, testing merupakan proses menjalankan program secara rutin untuk menemukan kesalahan dalam penulisan suatu pernyataan dalam program sedangkan debugging adalah proses menemukan kesalahan dalam program yang di perbaiki sampai tidak muncul kesalahan lagi.sebab sering terjsdi kasus yang berbeda antara satu program dengan program yang lainlangkah menulis program dan melakukan testing dan debugging bisa di lakukan berulang -ulang sampai program berjalam sesuai dengan yang di harapkan .

6. Melakukan dokumentasi,dokumen ini sangat penting untuk melakukan penelusuran jika terjadi kesalahan dan penting untuk pengembangan program.

7. Melakukan perawatan, Langkah terakir dalam pembuatan program adalah melakukan perawatan ,hal ini perlu di lakukan karena kemungkinan munculnya kesalahan di luar dugaan atau biasa pengguna meminta fasilitas yang baru dalam program. 


\section{Contoh - contoh bahasa pemrograman}

-Visual Basic

- Pascal

- Java

- PHP

- Delphi

- Borland $\mathrm{C}++$

Dalam pelajaran semester ini saya menggunakan bahasa pemrograman Borland $\mathrm{C}++$,, dalam borlan $\mathrm{C}++$ Agoritma sangat penting sekali karena dalam memasukan rumus rumusnya harus tepat dari input proses sampai output.

\section{Decision}

\section{Flowchart}

1. Flowchart adalah bagan-bagan yang mempunyai arus menggambarkan langkah-langkah penyelesaian suatu

masalah, Merupakan cara penyajian dari suatu algoritma. Ada 2 macam flowchart:

System flowchart Urutan proses dalam system dengan menunjukkan alat media input, output serta jenis penyimpanan dalam proses pengolahan data.

Program flowchart Urutan instruksi yang digambarkan dengan symbol tertentu untuk memecahkan masalah dalam suatu program.

\section{Simbol-simbol Flowchart}

1. Flow Direction Symbols (simbol penghubung alur)

2. Processing Symbols (simbol proses)

3. Input-Output Symbols (simbol input-output) 


\section{Pembuatan Flowchart}

1. Tidak ada kaidah yang baku

2. Flowchart $=$ gambaran hasil analisa suatu masalah

3. Flowchart dapat bervariasi antara satu pemrograman dengan pemrograman lainnya.

4. Secara garis besar ada 3 bagian utama:

- Input

- Proses

- Output

5. Hindari pengulangan yang tidak perlu dan logika yang berbelit sehingga jalannya proses menjadi singkat

6. Jalannnya proses digambarkan dari atas ke bawah dan diberikan tanda panah untuk memperjelas.

7. Sebuah Flowchart diawali dari satu titik START dan diakhiri dengan End

\section{STRUKTUR DATA}

Salah satu hal penting yang tidak dapat ditinggalkan dalam pemakaian komputer adalah data. Data dapat diperoleh dari berbagai sumber, misalkan hasil pengukuran laboratorium, hasil survei, hasil angket dan lain sebagainya. Komposisi data dan logika dari algoritma yang memanfaatkan data tersebut berhubungan sangat erat. Data sederhana dapat kita himpun ke dalam suatu struktur data yang memuat informasi tentang hubungan antara item yang terdapat di dalamnya. 


\section{Pengertian Struktur Data}

Dalam istilah ilmu komputer, struktur data adalah cara penyimpanan, pengorganisasian, dan pengaturan data di dalam media penyimpanan komputer sehingga data tersebut dapat digunakan secara efisien.

Dalam teknik pemrograman, struktur data berarti tata letak data yang berisi kolom-kolom data,baik itu kolom yang tampak oleh pengguna (user) ataupunkolom yang hanya digunakan untuk keperluan pemrograman yang tidak tampak oleh pengguna. Setiap baris dari kumpulan kolom-kolom tersebut dinamakan catatan (record). Lebar kolom untuk data dapat berubah dan bervariasi. Ada kolom yang lebarnya berubah secara dinamis sesuai masukan dari pengguna dan juga ada kolom yang lebarnya tetap.

Dengan sifatnya ini, sebuah struktur data dapat diterapkan untuk pengolahan database, misalnya untuk keperluan data keuangan, atau untuk pengolah kata (word processor) yang kolomnya berubah secara dinamis. Contoh struktur data dapat dilihat pada file-file spreadsheet, database, pengolahan kata, gambar yang dikompres, dan pemampatan file (kompres) dengan teknik tertentu yang memanfaatkan struktur data.

\section{Klasifikasi Data}

Pada garis besarnya, data dapat dikategorikan menjadi:

\section{A. Tipe Data Sederhana, yang terdiri dari:}

- Data Sederhana Tunggal, misalnya Integer, Real, Boolean, dan Karakter.

- Data Sederhana Majemuk, misalnya String.

\section{B. Struktur Data}

- Struktur Data Sederhana, misalnya Array dan Record.

- Struktur Data majemuk, terdiri dari:

o Linier, misalnya: Stack, Queue, dan Linier Linked List.

o Nonlinier, misalnya Binary Tree, Binary Search Tree, Graph, dll.

Pemakaian struktur data yang tepat di dalam proses pemrograman akan menghasilkan algoritma yang lebih jelas dan tepat, sehingga menjadikan program secara keseluruhan lebih efisien dan sederhana. 


\section{A. PENDAHULUAN}

Materi Kuliah Section 01 ini membahas Tentang Pengertian Algoritma Membahas Mengenai Langkah - langkah membuat Algoritma, Contoh - contoh Bahasa Pemrograman, Decision Flowchart, dan Struktur Data.

Maupun Algoritma merupakan jantung ilmu komputer atau pemrograman. Banyak cabang ilmu computer yang diacu dalam terminologi algoritma. Namun, jangan beranggapan algoritma selaluidentik dengan ilmu komputer saja. Dalam kehidupan sehari-haripun banyak terdapatproses yang dinyatakan dalam suatu algoritma. Cara-cara membuat kue atau masakan yangdinyatakan dalam suatu resep juga dapat disebut sebagai algoritma. Pada setiap resep selaluada urutan langkah-lankah membuat masakan. Bila langkah-langkahnya tidak logis, tidakdapat dihasilkan masakan yang diinginkan. Ibu-ibu yang mencoba suatu resep masakanakan membaca satu per satu langkah-langkah pembuatannya lalu ia mengerjakan prosessesuai yang ia baca. Secara umum, pihak (benda) yang mengerjakan proses disebutpemroses (processor). Pemroses tersebut dapat berupa manusia, komputer, robot atau alat-alat elektronik lainnya.

Pemroses melakukan suatu proses dengan melaksanakan atau“mengeksekusi" algoritma yang menjabarkan proses tersebut.Melaksanakan Algoritma berarti mengerjakan langkah-langkah di dalam Algoritma tersebut. Pemroses mengerjakan proses sesuai dengan algoritma yang diberikan kepadanya.Juru masak membuat kue berdasarkan resep yang diberikan kepadanya, pianis memainkanlagu berdasarkan papan not balok. Karena itu suatu Algoritma harus dinyatakan dalambentuk yang dapat dimengerti oleh pemroses. Jadi suatu pemroses harus Mengerti setiap langkah dalam Algoritma, Sebagai Berikut;

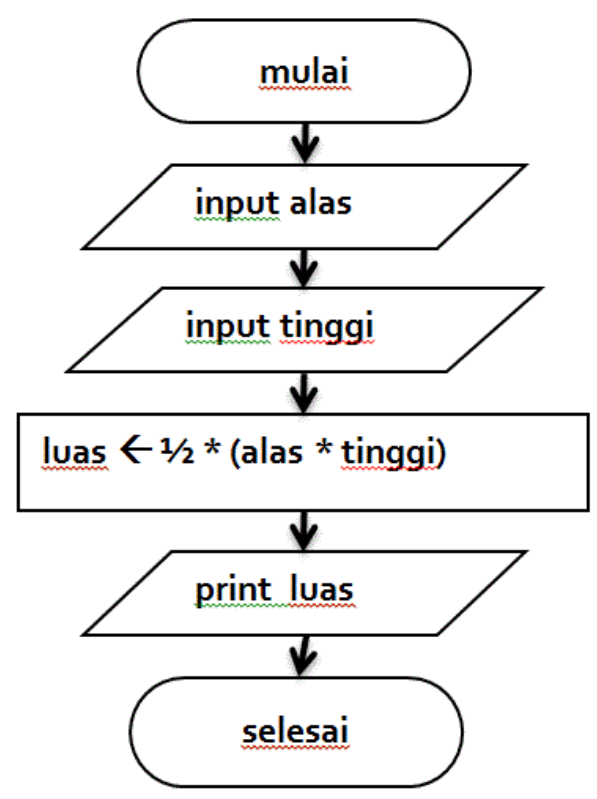

\begin{tabular}{l} 
Algoritma luas segitiga \\
Menghitung luas segitiga bila diketahui alas \\
dan tingginya \\
\hline input alas \\
input tinggi \\
luas $\leftarrow 1 / 2$ * (alas * tinggi) \\
print luas
\end{tabular}




\section{B. PEMBAHASAN / STUDI KASUS}

algoritma diartikan sebagai prosedur langkah demi langkah untuk memecahkan masalah atau menyelesaikan suatu tugas. Kamus Besar Bahasa Indonesia (KBBI) mendefinisikan algoritma sebagai urutan logis pengambilan keputusan untuk pemecahan masalah. sebuah susunan logis dan sistematis yang digunakan untuk memecahkan atau menyelesaikan suatu permasalahan tertentu. Meski begitu, jika dijabarkan lebih luas, terdapat beberapa arti algoritma yang disesuaikan dengan penggunaan bidangnya.

instruksi-instruksi tersebut menjelaskan sebuah komputasi yang, bila dieksekusi, diproses lewat sejumlah urutan kondisi terbatas yang terdefinisi dengan baik, Perlu diketahui juga bahwa logaritma adalah sebuah operasi di ilmu matematika guna menghitung kebalikan eksponen dari sebuah perpangkatan.

Kata Algoritma ditemukan oleh Abu Abdullah Muhammad Ibnu Musa Al-Khwarizmi, beliau merupakan matematikawan yang berasal dari Persia yang ditemukan pada Abad Ke 9. Dari masa ke masa, kata algoritma mulai berkembang di abad ke 18.

C. ID SECURITY

QWTD4452377-ASP-5244166

\section{KESIMPULAN}

Algoritma bisa kita ibaratkan sebagai otak dan jantung dari pemrograman, algoritma juga merupakan dasar dalam pemrograman, karena dengan memahami betul seluk beluk algoritma, maka kita akan mudah mempelajari bahasa pemrograman dan sebuah rangkaian proses 
komputasional yang mengkonversi satu atau beberapa masukan (input) menjadi satu atau beberapa keluaran (output) dan juga menyelesaikan permasalahan-permasalahan komputasional secara effiisien dan spesifk

\section{E. DISKUSI}

Saya M. Rizq Daffa Jodi dan Bersama Temen Saya Moh. Tegar Tri Prakoso Kami Mendiskusikan tentang materi ini dengan sangat baik, hasil diskusi dari materi ini adalah Kami Berdua Membahas Materi Ini Yang Kami Diskusikan Mengenai Pengertian Struktur Data, Pengertian Algoritma. Gambar Flowchart, Langkah langkah dan bahas pemrogramannya Beserta Contohnya, kami Simpulkan Secara Ringkas

\section{F.REFERENCE}

[1] O. M. Febriani and A. S. Putra, "Sistem Informasi Monitoring Inventori Barang Pada Balai Riset Standardisasi Industri Bandar Lampung," J. Inform., vol. 13, no. 1, pp. 90-98, 2014.

[2] A. S. Putra, "Paperplain: Execution Fundamental Create Application With Borland Delphi 7.0 University Of Mitra Indonesia," 2018.

[3] A. S. Putra, "2018 Artikel Struktur Data, Audit Dan Jaringan Komputer," 2018.

[4] A. S. Putra, "AlIAS MANAGER USED IN DATABASE DESKTOP STUDI CASE DB DEMOS."

[5] A. S. Putra, "COMPREHENSIVE SET OF PROFESSIONAL FOR DISTRIBUTE COMPUTING."

[6] A. S. Putra, "DATA ORIENTED RECOGNITION IN BORLAND DELPHI 7.0."

[7] A. S. Putra, "EMBARCADERO DELPHI XE 2 IN GPU-POWERED FIREMONKEY APPLICATION."

[8] A. S. Putra, "HAK ATAS KEKAYAAN INTELEKTUAL DALAM DUNIA TEKNOLOGY BERBASIS REVOLUSI INDUSTRI 4.0."

[9] A. S. Putra, "IMPLEMENTASI PERATURAN PERUNDANGAN UU. NO 31 TAHUN 2000 TENTANG DESAIN INDUSTRI BERBASIS INFORMATION TECHNOLOGY."

[10] A. S. Putra, "IMPLEMENTATION OF PARADOX DBASE."

[11] A. S. Putra, "IMPLEMENTATION OF TRADE SECRET CASE STUDY SAMSUNG MOBILE PHONE." 
[12] A. S. Putra, "IMPLEMENTATION PATENT FOR APPLICATION WEB BASED CASE STUDI WWW. PUBLIKLAMPUNG. COM."

[13] A. S. Putra, "IMPLEMENTATION SYSTEM FIRST TO INVENT IN DIGITALLY INDUSTRY."

[14] A. S. Putra, "MANUAL REPORT \& INTEGRATED DEVELOPMENT ENVIRONMENT BORLAND DELPHI 7.0."

[15] A. S. Putra, "PATENT AS RELEVAN SUPPORT RESEARCH."

[16] A. S. Putra, "PATENT FOR RESEARCH STUDY CASE OF APPLE. Inc."

[17] A. S. Putra, "PATENT PROTECTION FOR APPLICATION INVENT."

[18] A. S. Putra, "QUICK REPORT IN PROPERTY PROGRAMMING."

[19] A. S. Putra, "REVIEW CIRCUIT LAYOUT COMPONENT REQUIREMENT ON ASUS NOTEBOOK."

[20] A. S. Putra, "REVIEW TRADEMARK PATENT FOR INDUSTRIAL TECHNOLOGY BASED 4.0."

[21] A. S. Putra, "TOOLBAR COMPONENT PALLETTE IN OBJECT ORIENTED PROGRAMMING."

[22] A. S. Putra, "WORKING DIRECTORY SET FOR PARADOX 7."

[23] A. S. Putra, "ZQUERY CONNECTION IMPLEMENTED PROGRAMMING STUDI CASE PT. BANK BCA Tbk."

[24] A. S. Putra, D. R. Aryanti, and I. Hartati, "Metode SAW (Simple Additive Weighting) sebagai Sistem Pendukung Keputusan Guru Berprestasi (Studi Kasus: SMK Global Surya)," in Prosiding Seminar Nasional Darmajaya, 2018, vol. 1, no. 1, pp. 85-97.

[25] A. S. Putra and O. M. Febriani, "Knowledge Management Online Application in PDAM Lampung Province," in Prosiding International conference on Information Technology and Business (ICITB), 2018, pp. 181-187.

[26] A. S. Putra, O. M. Febriani, and B. Bachry, "Implementasi Genetic Fuzzy System Untuk Mengidentifikasi Hasil Curian Kendaraan Bermotor Di Polda Lampung," SIMADA (Jurnal Sist. Inf. dan Manaj. Basis Data), vol. 1, no. 1, pp. 21-30, 2018.

[27] A. S. Putra, H. Sukri, and K. Zuhri, "Sistem Monitoring Realtime Jaringan Irigasi Desa (JIDES) Dengan Konsep Jaringan Sensor Nirkabel," IJEIS (Indonesian J. Electron. Instrum. Syst., vol. 8, no. 2, pp. 221-232.

[28] D. P. Sari, O. M. Febriani, and A. S. Putra, "Perancangan Sistem Informasi SDM Berprestasi pada SD Global Surya," in Prosiding Seminar Nasional Darmajaya, 2018, vol. 1, no. 1, pp. 289-294. 
